Winter 2015

\title{
There Is No Such Thing as Litigation: Access to Justice and the Realities of Adjudication
}

Robert Rubinson

University of Baltimore School of Law, rrubinson@ubalt.edu

Follow this and additional works at: http://scholarworks.law.ubalt.edu/all_fac

Part of the Litigation Commons

\section{Recommended Citation}

There Is No Such Thing as Litigation: Access to Justice and the Realities of Adjudication, 18 J. Gender Race \& Just. 185 (2015)

This Article is brought to you for free and open access by the Faculty Scholarship at ScholarWorks@University of Baltimore School of Law. It has been accepted for inclusion in All Faculty Scholarship by an authorized administrator of ScholarWorks@University of Baltimore School of Law. For more information, please contact snolan@ubalt.edu. 


\title{
There is No Such Thing as Litigation: Access to Justice and the Realities of Adjudication
}

\author{
Robert Rubinson*
}

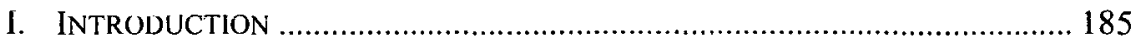

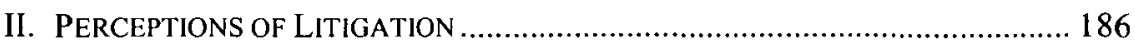

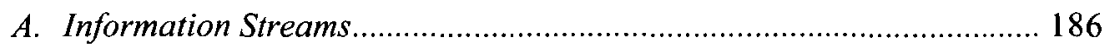

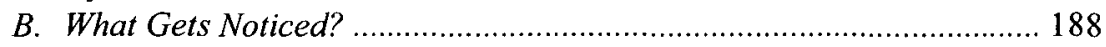

1. The Duke Lacrosse Players........................................................... 189

2. The O.J. Simpson Case .................................................................... 191

3. Media Coverage: The News and the Movie House .......................... 192

III. PERCEPTIONS Of LiTIGATION IN ACADEMIA: LAW STUDENTS ..................... 194

IV. PERCEPTIONS OF LITIGATION AMONG LAWYERS ....................................... 196

V. THERE is No SuCH THing AS "LiTigation": MASS AdjudiCATION........... 197

A. Civil Cases ................................................................................. 197

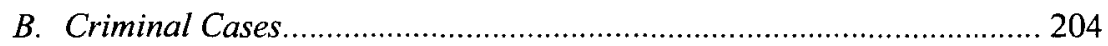

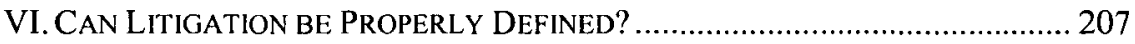

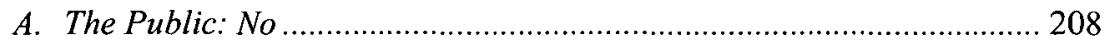

B. Law Students and Lawyers: Perhaps ................................................. 208

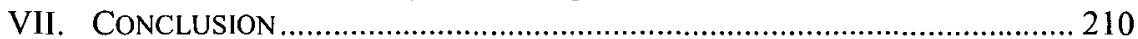

Lit·i'ga'tion: A legal contest by judicial process. ${ }^{1}$

Dic tio'nary: A reference book containing words or names typically important to a particular subject or activity along with discussion of their meanings and applications. ${ }^{2}$

\section{INTRODUCTION}

Does a "contest by judicial process" describe litigation's "means and applications"? Overwhelmingly, no. Litigation is not about judges: it is about default judgments, settlements, plea bargains. It sometimes does not even involve judges at all. ${ }^{3}$ Litigation is not about trials: the amount of litigation that goes to

\footnotetext{
* Dean Gilbert A. Holmes Professor of Clinical Theory and Practice, University of Baltimore School of Law. The author acknowledges receipt of a University of Baltimore summer research stipend in order to facilitate completion of this Article, and the research assistance of Lauren Vint. The author also gratefully acknowledges the assistance of Randi E. Schwartz.

I Webster's Ninth New Collegiate Dictionary (9th ed. 1988).

${ }^{2}$ Id.

${ }^{3}$ See infra text accompanying note 111 .
} 
trial is infinitesimal. ${ }^{4}$ It is not about "process": the process is so minimal that to dignify it with that term stretches the word beyond recognition. ${ }^{5}$ It is not a "contest": it is an exercise where one side has no plausible chance of winning, especially since that side either has no lawyers or lawyers with overwhelming caseloads to enforce whatever written rules do exist. ${ }^{6}$

This Article explores the reality of litigation by, first, examining some of the psychological bases for the power of the standard-and misleading - conception of how litigation is perceived. It then addresses how this definition omits the overwhelming amount of litigation as it truly is: litigation involving low income litigants in both civil and criminal cases. The Article concludes by examining whether public conception of litigation will ever reflect what "litigation" really is.

\section{Perceptions of Litigation}

Perceptions of litigation emerge from how cognition works, and then manifests itself among the lay public, law students, and lawyers themselves. What follows explores each of these topics.

\section{A. Information Streams}

There is extensive literature about how humans perceive what is in the world. ${ }^{7}$ Social psychologists in particular have developed an important insight: the brain includes, omits, and constructs perceptions of what is "out there." 8 This is not merely an element of cognition: it is cognition. For it to be otherwise would lead to, in William James' phrase, "a bloomin' buzzin' confusion."9

\footnotetext{
${ }^{4}$ See infra text accompanying notes $15,135-40$.

${ }^{5}$ See infra text accompanying notes 86-153.

${ }^{6}$ See infra text accompanying notes $92-121,141-45$.

${ }^{7}$ Citations to this literature would alone take a book. For a few seminal texts, see for example ANTHONY G. AMSTERDAM \& JEROME BRUNER, MINDING THE LAW (2000); RiCHARD NiSBETT \& LEE ROSS, HUMAN INFERENCE: STRATEGIES AND SHORTCOMINGS OF SOCIAL JUDGMENT (1980); JUDGMENT UNDER UNCERTAINTY: HEURISTICS AND BIASES (Daniel Kahneman et al. eds., 1982). Another rich and related area of research explores "categories"-how meaning is defined in terms of how situations and things fit within "prototypes." Raffaele Caterina, Comparative Law and the Cognitive Revolution, 78 TUL. L. REV. 1501, 1512 (2004); GEORGE LAKOFF, WOMEN, FIRE, AND DANGEROUS THINGS: What CATEGORIES REVEAL ABOUT THE MIND (1987).
}

${ }^{8}$ AMSTERDAM \& BRUNER, supra note 7, at 23 (cognition entails "conceptions of what matters); Anthony G. Greenwald, The Totalitarian Ego: Fabrication and Revision of Personal History, 35 AM. PSYCHOLOGIST 603, 606 (1908) (The brain "manage[s] knowledge in a variety of ways to promote the selective availability of information.").

${ }^{9}$ William James, Principles OF PSYchology (1890). 
Cognition thus limits how we view the world. We see what is before uswhat has been called the "information stream." 10 Things outside the "information stream" are invisible. This idea was well articulated by Francis Bacon in 1620: "things which strike the senses outweigh the things which do not immediately strike it, though they be more important." 11 This observation generates crucial consequences: we only see what is before us and assume that we and others act in accordance with what we see.

One idea in social psychology particularly relevant to the study of litigation is the concept of "scripts." 12 This concept explains how we act in a given situation based upon our "expectations" about how the world is supposed to be. ${ }^{13}$ As its name implies, a script is akin to acting in a play.

Consider the script for the conventional idea of litigation. ${ }^{14}$ The arrangement of a courtroom - the set of the play - is unvarying: it is adorned with flags, there is a raised bench in the front of the room, seats face the bench, there are chairs inside a "box" for a jury, there are tables with chairs in front of the bench. We also know how the play will unfold: judges enter while a voice instructs "all rise"; the judge wears robes and is addressed as "Your Honor"; the judge does not refer to herself through personal pronouns, but, rather, as "the Court"; no one "approaches the bench" without the judge's permission; lawyers stand or sit behind the table in front of the bench; the only people who speak directly to the judge are lawyers; witnesses are sworn in; lawyers ask them questions through direct and cross-examination; there are closing arguments; finally, the jury renders a verdict. ${ }^{15}$

\footnotetext{
${ }^{10}$ JON SIlverman, CRIME, POLICY AND THE MEDIA: THE ShaPING OF CRIMINAL JUSTICE, 1989-2010 5 (2012).

"Francis Bacon, The New Organon (1620), reprinted in Francis Bacon: A Selection of His WORKS 338 (Sidney Warhaft ed., 1965).

12 JEAN M. MANDLER, STORIES, SCRIPTS, AND SCENES: ASPECTS OF SCHEMA THEORY 94-108 (1984); Robert P. Abelson, Psychological Status of the Script Concept, 36 AM. PSYCHOLOGIST 715, 715-29 (1981); ROGER C. SCHANK \& ROBERT P. ABELSON, SCRIPTS, Plans, GoAls AND UNDERSTANDING: AN INQUIRY INTO HUMAN KNOWLEDGE STRUCTURES (1977).
}

${ }^{13}$ AMSTERDAM \& BRUNER, supra note 7, at 46. A classic example is the "restaurant script." We all know what to expect and how to act upon entering a restaurant. We are greeted, we are asked how many there are in a party, menus are distributed, a server arrives, food is served, questions are asked about the quality of the meal, the bill arrives, tips are calculated, and so on. There are also actors, the "dramatis personae" of the play. We know who they are and the parts they will play: chefs, the person who greets us upon arrival, servers, and so on. ROBERT J. STERnBERG \& KARIN STERNBERG, COGNITIVE PSYCHOLOGY 337-40 (6th ed. 2012).

\footnotetext{
${ }^{14} \mathrm{I}$ have addressed this issue previously in Robert Rubinson, Mapping the World: Facts and Meaning in Adjudication and Mediation, 62 ME. L. REV. 62, 76 (2010).

${ }^{15}$ One aspect of the litigation script is pervasive and entirely misleading: the frequency of trials. There are increasingly very few trials. The trend has been so pronounced that it has been called the "vanishing trial." Marc Galanter, The Vanishing Trial: An Examination of Trials and Related Matters in Federal and State Courts, 1 J. EMPIRICAL LEGAL STUD. 459 (2004). Given, however, that the "vanishing trial"
} 
The courtroom script expresses the powerful norms of litigation. ${ }^{16}$ Lawyers have the leading roles. There is formal adherence to process. Litigants are only heard through narrowly framed questions. There might be other players: cantankerous judges, overreaching prosecutors, ${ }^{17}$ unscrupulous defense attorneys, ${ }^{18}$ lying witnesses, and so on. But the script remains. As a result, rare variations from the script shock because of how they powerfully subvert what is expected. Consider Al Pacino famously shouting to a judge: "You're out of order! This whole trial's out of order!"19 In light of the litigation "script," the language is telling. The script has become, literally, out of order: it turns on its head the ironclad sequence and hierarchies of the litigation script which, in turn, reaffirms how entrenched the script is. ${ }^{20}$

\section{B. What Gets Noticed?}

So what sorts of cases trigger intense and prolonged media scrutiny? The following formula ${ }^{21}$ offers one way of approaching the question:

(Fame of Defendant $)^{22} \times$ (Affluence $^{23} \times$ (Criminal Case $^{24}=($ Intensity of Coverage) + (Length of Coverage)

cuts across both what this Article argues is real litigation as well as the misleading script of "litigation," the misimpression is not a focus of this Article.

${ }^{16}$ The raised bench, the deference, the flags reflect, as Robert Cover famously observed, the power of state-sanctioned "violence" against litigants through enforcement of judgments, incarceration, and, potentially, death. ROBERT COVER, VIOLENCE AND THE WORD, reprinted in ROBERT COVER, NARRATIVE, Violence, AND THE LAW: The EsSAys OF RoBert COVER 203-38 (Martha Minow et al. eds., 1993).

17 This is a common element of media portrayals of prosecutors. Robert Rubinson, Professional Identity as Advocacy, 31 Miss. C. L. REv. 7, 27-29 (2012).

${ }^{18}$ Id. at $29-30$.

19 ... AND JUSTICE FOR AlL (Columbia Pictures 1979).

${ }^{20}$ Anthony G. Amsterdam and Jerome Bruner interestingly identify scripts as the "hidden cargo" of narratives, and, to continue the metaphor, screaming calling a judge "out of order" rather than the judge saying someone else is out of order is akin to throwing the cargo overboard. AMSTERDAM \& BRUNER, supra note 7, at 121 .

${ }^{21}$ An earlier version of this formula appeared in Following Trials that Really Matter, DAILY RECORD BALTIMORE, MD, Nov. 26, 2004, at 15A. For an exploration and gathering of authorities on this topic, see Pauline K. Brennan \& Abby L. Vendenberg, Depictions of Female Offenders in Front-Page Newspaper Stories: The Importance of Race/Ethnicity, 2 INT'L J. OF SOC. INQUIRY 141 (2009).

${ }^{22}$ Sharon L. Davies, The 192I Headline Trial, Alabama v. Edwin R. Stephenson-Seeing Ourselves in a Grain of Sand, 55 ST. LoUIS U. L.J. 1317, 1319 (2011) (citing Professor Lawrence Friedman).

${ }^{23}$ Prominent examples are O.J. Simpson and the Duke Lacrosse Players, both discussed below. See infra text accompanying notes 30-33, 51-52.

${ }^{24}$ Overwhelmingly, criminal, not civil, cases garner virtually all media attention. RAY SURETTE, Media, CRime, and Criminal Justice: Images, Realities, and Policies 121 (3d ed. 2007) (explaining that "[a]lthough criminal law is only one area of the law and in the real world most 
While millions of criminal defendants are prosecuted each year, ${ }^{25}$ virtually none are famous or affluent. ${ }^{26}$ As a result, the percentage of criminal matters that reach public consciousness is infinitesimal. ${ }^{27}$ The situation on the civil side is, if possible, even more extreme. The untold numbers of civil case-both administrative and judicial-are, overwhelmingly, "zeroes" in terms of fame, affluence, and (of course) being a criminal case. Apart from the occasional celebrity divorce, no civil cases reach public consciousness. In the end, then, a tiny number of criminal cases define what is perceived as litigation.

The following describes the formula in action by examining the extraordinarily rare characteristics of cases covered by the popular media.

\section{The Duke Lacrosse Players}

In 2006, three college athletes attending Duke University were accused of raping an African-American woman at a party. ${ }^{28}$ The athletes were white. ${ }^{29}$ The accused in the Duke Lacrosse Players case (as it came to be known) were different from "typical" criminal defendants. ${ }^{30}$ The players were well-off and students at an elite college. Their case engendered intense media scrutiny that extended over a year. ${ }^{31}$ In contrast, "typical" criminal defendants are poor and uneducated. ${ }^{32}$ Only a tiny percentage of cases involving such defendants are noticed. The few that are noticed -often cases involving violent felonies - might trigger coverage

attorneys practice other specialties, most lawyers in the media are criminal lawyers and specialize in criminal law.").

${ }^{25}$ Public defender programs in twenty-two states handled 1,491,420 cases. DONALD J. FAROLE, JR. \& LyNN LANGTON, BurEau OF JUSTICE STATISTICS, U.S. DEP'T OF JUSTICE, COUNTY-BASEd AND LoCAl Public Defender OfFices, 20073 (2010). The total number nationally is many millions more: the study did not count cases in the most populous states, including California, Texas, New York, Florida, Illinois, and Pennsylvania. See id. at 1-3.

${ }^{26}$ See generally Caroline Wolf Harlow, Bureau of Justice Statistics, U.S. DeP'T OF Justice, DEFENSE COUNSEL IN CRIMINAL CASES 1 (2000). An important government study found that $80 \%$ of criminal defendants live in poverty. See id.

${ }^{27}$ James Garofolo, Crime and the Mass Media: A Selective Review of Research, 18 J. RES. CRIME \& DELINQUENCY 319, 322-23 (1981).

${ }^{28}$ Robert P. Mosteller, The Duke Lacrosse Case, Innocence, and False Identifications: A Fundamental Failure to "Do Justice", 76 FORDHAM L. REV. 1337 (2007)

${ }^{29}$ Robert M. Entman \& Kimberly A. Gross, Race to Judgment: Stereotyping Media and Criminal Defendants, 71 LAW \& CONTEMP. PROBS. 93, 107 (2008).

${ }^{30} I d$. at 94 (noting 'the amount of attention devoted to the injustices suffered by the Duke students' relative to the attention given to potential injustices suffered by more-typical defendants.").

${ }^{31} / d$. at 110 . The media scrutiny extended from March 2006 to April 2007. See id.

${ }^{32}$ See Melissa Hickman Barlow, Race and the Problem of Crime in Time and Newsweek Cover Stories, 1946 to 1995, 25 SoC. Just. 149 (1998); Steven Chermak, Predicting Crime Story Salience: The Effects of Crime, Victim, and Defendant Characteristics, 26 J. CRIM. JUST. 61 (1998). 
on local news outlets, but such stories blend into one another after a day or two of coverage. ${ }^{33}$

In the end, the charges against the Duke Lacrosse players were dismissed and the prosecution of the case was almost universally condemned. ${ }^{34}$ The prosecutor, Mike Nifong, withheld evidence exonerating the defendants. ${ }^{35} \mathrm{He}$ was found to be a "rogue prosecutor" by the North Carolina Attorney General ${ }^{36}$ and was subsequently disbarred. ${ }^{37}$ The injustice of the case led to widespread outrage, including the publication of books ${ }^{38}$ and articles in the media ${ }^{39}$ and academia. ${ }^{40}$

Indeed, the outcry was so intense that it led to, at best, dubious comparisons to other cases. One particularly troubling example is a book characterizing the case as a "modern Scottsboro" - as if the situation of the Duke Lacrosse players was analogous to what the Scottsboro Boys faced: threats of lynching, one day trials, and death sentences for African-Americans reflecting the deep-seated oppression, hostility, and violence in the Jim Crow South of the 1930's. ${ }^{41}$ In contrast, the Duke Lacrosse case, while unjust, did not reflect widespread oppression of student athletes at elite universities.

In any event, the Duke Lacrosse case saturated the media, and what was portrayed still operated within the perceived norms of litigation:

\footnotetext{
${ }^{33}$ See supra note 32; Jon Hurwitz \& Mark Peffley, Public Perceptions of Race and Crime: The Role of Racial Stereotypes, 41 AM. J. POL. SCI. 375 (1997).

34 See Race to InJustice: Lessons Learned fRom the Duke LaCrosse RaPE CASE (Michael L. Seigel, ed. 2008); Mosteller, supra note 28.

${ }^{35}$ See sources cited supra note 34.

${ }^{36}$ Duff Wilson \& David Barstow, All Charges Dropped in Duke Case, N.Y. Times (Apr. 12, 2007), http://www.nytimes.com/2007/04/12/us/12duke.html?_r=0.

${ }^{37}$ Robert P. Mosteller, Exculpatory Evidence, Ethics, and the Road to the Disbarment of Mike Nifong: The Critical Importance of Full Open-File Discovery, 15 GEO. MASON L. REV. 257 (2008).

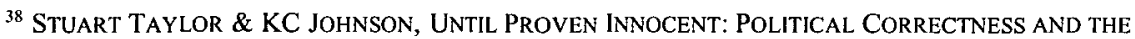
Shameful InJUSTICES OF THE DUKE LACROSSE RAPE CASE (2008).

39 See R. Taylor Matthews III, Comment, The Duke Lacrosse Rape Case - A Public Branding, Is There a Remedy?, 25 ST. LouIS U. L.J. 669, 670 (2008) (referring to an "avalanche" and "deluge" of media coverage).

${ }^{40}$ David A. Elder, A Libel Law Analysis of Media Abuses in Reporting on the Duke Lacrosse Fabricated Rape Charges, 11 VAND. J. ENT. \& TECH. L. 99 (2008); Dan Subotnik, The Duke Rape Case Five Years Later: Lessons for the Academy, the Media, and the Criminal Justice System, 45 AKRON L. REV. 887 (2012); Mosteller, supra note 28.

41 R.B. Parrish, The Duke LaCrosse CaSe: A Documentary History and Analysis of the MODERN SCOTTSBORO (2009). The case is notable for the Supreme Court's holding of the right to counsel in federal cases. Powell v. Alabama, 287 U.S. 45 (1932). Powell's recognition of a "right to counsel" in criminal cases - a right broadly recognized in Gideon v. Wainwright-has not generated individualized representation of criminal defendants. Gideon v. Wainwright, 372 U.S 335 (1963).
} 
- The defendants were represented to the utmost by attorneys who, as far could be seen, had no other cases to work on.

- The judicial system lavished individualized attention on the case and the treatment of the defendants.

- The prosecutor did not press for an immediate plea bargain.

Thus, while unjust, the Duke Lacrosse case reaffirmed prevailing views of litigation. The "litigation" script ${ }^{42}$ remained very much in place.

\section{The O.J. Simpson Case ${ }^{43}$}

The greatest adjudicative earthquake of the last fifty years was the O.J. Simpson case. Despite the passage of time, the case has retained its status as "the most publicized murder trial in American history," 44 if not, as some have said, all of history. ${ }^{45}$

O.J. Simpson was the preeminent football player of his time. His fame led to appearances in advertising, television, and film. In 1994, Simpson was accused of murdering Nicole Brown-Simpson, his ex-wife, and Ronald Goldman, a waiter who was returning Brown-Simpson's mother's glasses that were left in a restaurant where Goldman worked. The case triggered an explosion of public attention even before legal proceedings commenced, when a bizarre and prolonged car chase was widely broadcast on live television. The drama continued unabated from arrest to a not guilty verdict rendered by the jury in 1995, and subsided only when commentary on the verdict ran its course. Simpson's lawyers (some of whom were well-known prior to the Simpson case ${ }^{46}$ ), the prosecutors, ${ }^{47}$ witnesses, and the presiding judge all gained measures of fame. The trial took over eight months. During the period just prior to and when the jury announced

\footnotetext{
${ }^{42}$ See supra text accompanying notes $12-15$.

${ }^{43}$ This Article will not go into detail about the facts of the case on the assumption they are well known. Countless articles and over twenty books have been written about the case, many by central figures in the trial, including Simpson himself. As to academia, a Westlaw search returned forty-six articles with Simpson's name in the title, and 4,420 where the Simpson case is cited or discussed. For an overview of the case that is less sensationalized than most, see JEFFrEY TOOBIN, THE RUN OF HIS LIFE: THE PEOPLE VERSUS O.J. SiMPSON (1996).

44 Joanne Armstrong Brandwood, Note, You Say "Fair Trial" and I Say "Free Press": British and American Approaches to Protecting Defendants' Rights in High Profile Trials, 75 N.Y.U. L. Rev. 1412,1413 n.5 (2000).

${ }^{45}$ Jonathan M. Remshak, Comment, Truth, Justice, and the Media: An Analysis of the Public Criminal Trial, 6 SETON HALl CONST. L.J. 1083, 1085 (1996).

46 The primary trial attorneys were Johnnie Cochran, F. Lee Bailey, Robert Kardashian, and Robert Shapiro. Alan Dershowitz assisted, and two experts in DNA analysis, including, most memorably, Barry Scheck, also represented Simpson.

${ }^{47}$ The lead prosecutor was Marcia Clark. Media scrutiny of Clark reached such absurd levels that her change of hairstyle generated substantial media coverage. See Richard Gabriel, "This Case Is Brought to You By. . .": How High-Profile Media Trials Affect Juries, 33 LoY. L.A. L. REV. 725, 727 (2000).
} 
its verdict, "long distance telephone calls dropped by $58 \%$ and trading volume on the New York Stock Exchange fell by $41 \%[] "$.48 This pause in the everyday business of the country is estimated to have cost the United States' economy $\$ 480$ million. ${ }^{49}$

The verdict generated its own frenzy of controversy, with reactions to the verdict falling along racial lines. ${ }^{50}$ This is no surprise given the swirl of racial issues infusing the trial: an African-American defendant allegedly murdered his white ex-wife and another white victim; the defendant's lead counsel was accused by some of using race in Simpson's defense; and a majority of the jurors were African-American.

The Simpson case not only "struck the senses" but overwhelmed them. It was the adversary system on steroids. Enormous resources were expended including lawyers who appeared to be handling no other cases, a jury selection process that lasted well over a month, minute and detailed examination of evidence, the retention and testimony of numerous experts, attorneys delivering extended opening statements and closing arguments, an intensely focused trial judge who, seemingly, had no other judicial business to attend to. Many concluded that Simpson's chances of acquittal were negligible without his ability to retain many high-priced defense attorneys. ${ }^{51}$ Nevertheless, the overall process was still familiar, albeit far more expansive and expensive than what most defendants less rich and famous could afford. Many-especially whites-concluded that the Simpson verdict was wrong, that Simpson, literally, got away with murder. ${ }^{52}$ For these observers the result was tainted, but the process, although bloated, was not bloated beyond recognition: it was still, as popularly understood, litigation underneath all its lavishness.

\section{Media Coverage: The News and the Movie House}

The rise of technology, including twenty-four hour cable channels and access to the internet, has intensified media coverage of sensationalized cases. Court TV, which began in 1991, rose to prominence through another celebrity trial-that of William Kennedy Smith, a nephew of John and Robert Kennedy, who was

\footnotetext{
${ }^{48} / d$. at 725 .

${ }^{49}$ Id.

${ }^{50}$ African-Americans tended to support Simpson's exoneration while Whites believed Simpson should have been convicted. The distinction has been shown empirically. Christo Lassiter, The O.J. Simpson Verdict: A Lesson in Black and White, 1 MiCH. J. RACE \& L. 69 (1996).

${ }^{\text {s1 }}$ Angelique M. Paul, Note, Turning the Camera on Court TV: Does Televising Trials Teach Us Anything About the Real Law?, 58 OHIO ST. L.J. 655, 685 (1997).

${ }^{52}$ As with so much else relating to the Simpson trial, the number of citations for this proposition could go on for a very long time. Two examples with similar titles: VINCENT BUGLIOSI, OUTRAGE: THE FIVE REASONS WHY O.J. SiMPSON GOT AWAY WITH MURDER (1996); MIKE GILBERT, HOW I HELPED O.J. GET AWAY WITH MURDER (2008).
} 
accused of rape in that year. ${ }^{53}$ Court TV truly burst into prominence, however, four years later as a result of the Simpson case. ${ }^{54}$ Some shows are now solely devoted to coverage of "the law" 55 and legal commentators abound ${ }^{56}$ Much of this media treatment is presented point/counterpoint fashion reflecting the different mindsets of defense attorneys and prosecutors - a reflection of the conventional adversary system itself.

Nevertheless, the vanishingly small category of cases that garner media attention is not a function of advancing technology. To the contrary, infamous cases of earlier times were still criminal cases in which the accused was famous and/or wealthy. Examples include the 1925 murder trials of Leopold and Loeb, in which the defendants were affluent University of Chicago Law School students, ${ }^{57}$ or the 1934 trial of the accused kidnapper in the Charles Lindbergh baby case, in which the father of the victim was the most widely admired American hero of his time. ${ }^{58}$ The formula holds. ${ }^{59}$ The minute subset of cases characterized by wealth and celebrity has defined how litigation is viewed in the public imagination for a very long time. ${ }^{60}$

Apart from media coverage, countless films portray lawyers. Virtually all depict popular conceptions of litigation. Consider the few that have become memorable enough to have entered public consciousness. These films include comedies like $M y$ Cousin Vinny, ${ }^{61}$ with its depiction of legal inexperience and culture clashes in rural Alabama, and Legally Blonde, ${ }^{62}$ which presents a highprofile murder case in which the accused is represented by a Harvard Law Professor. Dramas include ... And Justice for All ${ }^{63}$ and, perhaps most famous

${ }^{53}$ Paul, supra note 51, at 662.
${ }^{54}$ Id. at 663.
${ }_{55}$ Benjamin Levin, De-Naturalizing Criminal Law: Of Public Perceptions and Procedural Protections, 76 ALB. L. REV. 1777, 1783-84 (2013) (referring to television host Nancy Grace as displaying the "overwrought absolutism" of the prosecutor point of view).

56 This concern has led to discussions about "ethical code for legal commentators." For an overview of this debate, see Jacquenette M. Helmes, Note, An Ethical Code for Legal Commentators: What Is Its Value?, 12 GEO. J. LEGAL ETHICS 767 (1999).

${ }^{57}$ Hal Higdon, The Crime of the Century: The Leopold and loeb Case (1975).

${ }^{58}$ The accused kidnapper was Bruno Richard Hauptmann. Hauptmann was subsequently convicted and executed. William A. COOK, THE LiNDBERGH BABY KidNAPPING (2014).

${ }^{59}$ See supra text accompanying notes $21-24$.

${ }^{60}$ Interestingly, at least one book includes the O.J. Simpson, Leopold and Loeb, and the Lindbergh baby case as, collectively, "crimes of the century." GILBERT GEIS \& LEIGH B. BIENEN, CRIMES OF THE CENTURY: FROM LEOPOLD AND LOEB TO O.J. SIMPSON (1998).

${ }^{61}$ MY Cousin VINNY (20th Century Fox 1992).

${ }^{62}$ LEGALLY Blonde (Metro-Goldwyn-Mayer 2001).

${ }^{63}$ See supra text accompanying note 19. 
of all, To Kill a Mockingbird, ${ }^{64}$ with its compelling story of integrity and justice and injustice in the segregated south. Whether comedic, ennobling, or overwrought, all portray litigation in all of its conventional procedural trappings. It is also notable that all portray criminal defense - the type of case that almost invariably captures public attention. ${ }^{65}$

\section{Perceptions of Litigation in ACAdemia: LAW StudenTs ${ }^{66}$}

The Law School curriculum is driven by the "case method." 67 To state the obvious, cases are the foundation of the case method. The oft-stated goal of legal education- "thinking like a lawyer"-entails analyzing cases and "synthesizing" rules from cases. ${ }^{68}$ The originator of the case method was Christopher Columbus Langdell, Dean of Harvard Law School in the nineteenth century. Langdell himself, as memorably described by Jerome Frank, believed "that 'all the available materials ... are contained in printed books" and "had an obsessive and almost exclusive interest in books." ${ }^{69}$ His case method embodied this belief.

The "case method" is a misnomer because virtually no cases generate written judicial opinions. ${ }^{70}$ In fact, the "case method" is really the "appellate opinion method," and appellate opinions have distinctive characteristics. Appellate cases have lawyers. "Facts" are assumed. Appellate opinions tend not to focus much on

\footnotetext{
64 To KILL A MOCKINGBIRD (Universal Pictures 1962).

${ }^{65}$ See supra text accompanying notes $21-27$. One popular film that does break the mold to a degree is The Paper Chase, with its indelible portrayal of Harvard Law School Professor Kingsfield. THE PAPER CHASE (20th Century Fox 1973). Kingsfield is a model of the imperious law school professor intent on humiliating terrified students in order to, as he puts it, make "a skull full of mush ... think[] like a lawyer." Nevertheless, this film still focuses on an elite law school education and certainly does not address the mass of litigation discussed in this article. See infra text accompanying notes 86-153.

${ }^{66}$ This section will defer addressing clinical legal education, upon which the Article will focus. Infra text accompanying notes 159-64.

${ }^{67}$ Robert SteVens, LAW SCHOOL: Legal EduCATION IN AMERICA From THE 1850S TO THE 1980S 52-53 (1983); Margaret Martin Barry, et al., Clinical Education for this Millennium: The Third Wave, 7 CLINICAL L. REV. 1, 2-3 (2000).

${ }^{68}$ See Paul Figley, Teaching Rule Synthesis with Real Cases, 61 J. LEGAL EDUC. 245, 246 (2011) (discussing the "principles of rule synthesis" from appellate opinions).

${ }^{69}$ Jerome Frank, Why Not a Clinical Lawyer-School?, 81 U. PA. L. REV. 907-08 (1933). In Langdell's defense, one article has characterized Langdell as a "straw man" for "simplistic (if not simple-minded) formalism." Catharine Pierce Wells, Langdell and the Invention of Legal Doctrine, 58 BuFF. L. REV. 551,552 (2010). In any event, Langdell is seen, whether fairly or unfairly, as the father of the case method.

${ }^{70}$ Consider the massive numbers of adjudicated cases with pro se litigants which are resolved in minutes-hardly the sorts of cases that generate judicial opinions. See infra text accompanying notes $87-121$.
} 
clients as individuals: they are merely stick figures embedded in a "fact pattern." The appellate focus of law school also extends to the multiplicity of moot courtsanother place where the role of clients is solely to facilitate the presentation of arguments about legal doctrine.

Very rarely do other views of litigation creep into "doctrinal" courses in law school. To take a rare example, one property text makes reference to low-income tenants in eviction cases. ${ }^{72}$ In the "Notes and Questions" regarding retaliatory eviction, the full reference to such tenants is as follows:

For a study showing that legal services attorneys represent poor and minority tenants with strong defenses to eviction, and that raising these defenses does not pose significant costs on landlords, see Gunn, Eviction Defense for Poor Tenants: Costly Compassion or Justice Serviced?, 13 Yale L. \& Pol'y Rev. 385 (1995). ${ }^{73}$

Consider what the author does and does not describe. There is no reference that the cited study found legal services attorneys who represented the "extremely poor . . . were able to prevent or delay their evictions, helping the tenants either to remain in their homes or to secure alternate housing without suffering sudden dislocation or homelessness." 74 The author focuses solely on the financial impact of such representation on landlords, not tenants. Even this rare mention of litigation involving low-income participants is only in "Notes and Questions" on the doctrine of retaliatory eviction. It is supplemental and non-essential.

One specific course that does ostensibly focus on attorneys and clients is Professional Responsibility-a class law schools must offer in order to be accredited by the American Bar Association. ${ }^{75}$ The subject of professional responsibility or "legal ethics" has grown rapidly in recent years, and the lawyers" rules of professional conduct have been revised with increasing frequency. ${ }^{76}$ The bulk of these courses examine the ABA Rules of Professional Conduct in detail and rarely delve into anything apart from a generalized view of what lawyers do.

\footnotetext{
"I have elsewhere explored the simplicity of the presentation of "facts" in appellate cases in Robert Rubinson, Attorney Fact-Finding, Ethical Decision-Making and the Methodology of Law, 45 ST. LOUIS U. L.J. 1185 (2001).

72 David L. Callies et al., Concise InTroduction to Property Law 568 (2011).

${ }^{73}$ Id. at 569 .

74 Steven Gunn, Note, Eviction Defense for Poor Tenants: Costly Compassion or Justice Serviced?, 13 YALE L. \& POL'Y REV. 385, 421 (1995).

${ }^{75}$ ABA Standards for Approval of Law Schools, Standard 302 (a)(5) (requiring "substantial instruction in . . . the history, goals, structure, values, rules and responsibilities of the legal profession and its members").

${ }^{76}$ See Charles W. Wolfram, Toward a History of the Legalization of American Legal Ethics-II. The Modern Era, 15 GeO. J. LeGAL ETHICS 205, 206 (2002).
} 
Some leading textbooks do explore the realities of litigation beyond the rules by exploring the massive numbers of unrepresented litigants. ${ }^{77}$ This treatment, however, can go from relatively substantial ${ }^{78}$ to nonexistent. ${ }^{79}$

In the end, most courses on professional responsibility focus on the doctrine of the "law governing lawyers." school, avoids the messiness of reality and assumes a process that reflects widely accepted norms of how litigation operates.

\section{PERCEPTIONS OF LiTIGATION AMONG LAWYERS}

Law students become lawyers, and thereafter practicing law becomes reality. Due to what has been called assuming "the normativity of experience," understanding of what lawyers do depends primarily upon what a particular lawyer does. Having only represented organizations ${ }^{82}$, or personal injury clients, or middle-class clients in family law, or advising clients about trusts and estates, or representing individuals or organizational clients in "transactional" lawyers, most attorneys know nothing of the places where low-income litigants go because few lawyers go there. ${ }^{83}$

The lawyers who do go to such places-public interest lawyers engaged in individual representation-constitute a tiny percentage of the profession as a

77 Lisa G. Lerman \& Philip G. Schrag, Ethical Problems in the Practice of Law 790-96 (3d ed. 2012).

${ }^{78}$ Id. at 789-848 (includes a chapter devoted to problems relating to the "provision of legal services").

79 Thomas D. Morgan et Al., Professional Responsibility: Problems and Materials (1 1 th ed. 2011). This has long been the leading text for professional responsibility classes, although less so as the subject has matured and more texts proliferate.

${ }^{80}$ This term has gained currency with the relatively recent addition of the Restatement (Third) of the Law Governing Lawyers (2000).

${ }^{81}$ Dale W. Griffin \& Less Ross, Subjective Construal, Social Inference, and Misunderstanding, in 24 ADVANCES IN EXPERIMENTAL SoCIAL PSYCHOLOGY 319, 337-38 (Mark P. Zann ed., 1991).

82 Increasing numbers of lawyers represent organizations and not individuals. The most recent statistics are from 2005 , which showed that $64 \%$ of lawyers represent organizations. JOHN P. HEINZ, ET AL., URBAN LAWYERS: THE NEW SOCIAL STRUCTURE OF THE BAR 29 (2005). This figure has likely grown since then.

${ }^{83}$ See Robert Rubinson, A Theory of Access to Justice, 29 J. LEGAL Prof. 89, 92-99 (2005). 
whole. ${ }^{84}$ The result: $1 \%$ of a $\$ 100$ billion legal industry is devoted to the needs of low-income Americans. ${ }^{85}$

\section{There is No SuCh Thing as "Litigation": MASS AdJudication}

Sensational cases are vanishingly rare: after all, if it were otherwise, they would not be sensational. In fact, vanishingly rare is an overstatement: their numbers are infinitesimal as compared to the volume of criminal cases, and zero in terms of the civil justice system because sensational cases are all criminal cases ${ }^{86}$ What follows is what litigation really is for virtually all litigants.

\section{A. Civil Cases}

As the New York Court of Appeals has said, "many kinds of private litigation ... drastically affect indigent litigants [including] eviction ... mortgage foreclosures, [and] repossession of important assets," but "courts and litigants must make do with what exists." ${ }^{17}$ Stephen Wexler offered a more pungent summary: "poor people are always bumping into sharp legal things." 88 As far as civil litigation is concerned, this has been called "crisis" for so long ${ }^{89}$ that the "crisis" appears to be never-ending. ${ }^{90}$ This, in fact, means it is not a crisis at all

${ }^{84}$ David Luban, Essay, Taking Out the Adversary: The Assault on Progressive Public-Interest Lawyers, 91 CALIF. L. REV. 209, 211 (2003) (explaining there is "about one lawyer for every 240 nonpoor Americans" and "one lawyer for every 9000 Americans" who would qualify for legal aid). No doubt a crucial aspect of this reality of modern law practice is the yawning disjunction between what public interest lawyers get paid and what lawyers in private practice, particularly in large law firms, get paid. NALP (Nov. 2011), Starting Salaries-What New Law Graduates Earn-Class of 2010, http://www.nalp.org/starting_salaries_-_what_new_law_graduates_earn_-_class_of_2010.

${ }^{85}$ Luban, supra, note 84 . One explanation for these findings is, as noted above, increasing numbers of lawyers are representing for-profit organizations. JOHN P. HEINZ \& EDW ARD O. LAUMANN, CHICAGO LAWYerS: The SOCIAL STRUCTURE OF THE BAR (2d ed. 1994); HeINZ, ET Al., supra note 82.

${ }^{86}$ See supra text accompanying notes $21-27$.

${ }^{87}$ In re Smiley, 330 N.E.2d 53, 57-58 (N.Y. 1975).

${ }^{88}$ Stephen Wexler, Practicing Law for Poor People, 79 YALE L.J. 1049, 1050 (1970).

89 Access to Justice, About the Initiative, U.S. DEP'T OF JUSTICE (Aug. 2012), http://www.justice.gov/atj/about-atj.html ("[G]aps in legal services for the poor and middle class constitute not just a problem, but a crises . . . as difficult and intransigent as any now before us."). Some thirty years earlier, Jerold S. Auerbach noted how "judges and lawyers have monotonously conceded . . . that legal institutions have defaulted on their obligations to provide justice for all," but the concession has not triggered change. JEROLD S. AUERBACH, JUSTICE WITHOUT LAW? RESOLVING DISPUTES WITHOUT LAWYERS 143-44 (1983)

${ }^{90}$ This is the case even though there have been good faith attempts to improve the situation. For example, there are many "access to justice commissions," directories, web sites, pro se assistance in various forms, and the like. ABA RESOURCE CENTER FOR ACCESS TO JUSTICE INITIATIVES, REPORT TO THE CCJ/COSA: COMmITTEE ON ACCESS, FAIRnESS AND PuBliC TRuSt (2012). As described infra, these efforts have had little impact in redressing the problem.

Another area of much discussion relates to the ABA Model Rules of Professional Conduct. Consider the Preamble of Model Rules: 
because a "crisis" is "an unstable or crucial time or state of affairs in which a decisive change is impending." Unfortunately the situation is quite stable. No decisive change is in sight.

The vast majority of all low-income litigants are unrepresented.$^{92}$ Some have recognized how profoundly troubling this is and have sought to remedy it. One prominent effort has been to seek recognition of a Civil Gideon-a right to counsel in civil cases, ${ }^{93}$ or, more modestly, a right to counsel in specific types of cases. ${ }^{94}$ While there have been successes in this effort, the few examples are narrowly circumscribed. ${ }^{95}$ Even if successful, whether such recognition could

\begin{abstract}
A lawyer should be mindful of the deficiencies in the administration of justice and of the fact that the poor, and sometimes persons who are not poor, cannot afford adequate legal assistance. Therefore, all lawyers should devote professional time and resources and use civic influence to ensure equal access to our system of justice for all those who because of economic or social barriers cannot afford or secure adequate legal counsel.
\end{abstract}

MODEl RUles of Prof'L CONDUCT Preamble 6 (2013). The Model Rules, however, do not obligate lawyers to do anything about this "deficiency" either through pro bono or any other steps. See Id. R. 6.1 (providing that lawyers "should" engage in voluntary pro bono public service). The prior, and first, modem set of ethical responsibilities - the ABA Model Code of Professional Responsibility adopted in 1970-similarly proclaims how a lawyer should assist the legal profession in fulfilling its duty to make legal counsel available. MODEL CODE OF PROF'L RESPONSIBILITY Canon 2 (1980). None of these rules require pro bono work.

${ }^{91}$ MERRIAM-WEBSTER'S COLLEGIATE DiCTIONARY 296 (11 th ed. 2004).

92 DEBORAH L. RHODE, ACCESS TO JUSTICE 5 (2004) (explaining that "[i]n most family, housing, bankruptcy, and small claims courts, the majority of litigants lack legal representation ... [Yet] too little effort has been made to ensure that it is fair or even comprehensible to the average claimant.").

${ }^{93}$ Such arguments have been made as far back as 1923. John MacArthur Maguire, Poverty and Civil Litigation, 36 HARV. L. REV. 361 (1923). For a recent overview, see Debra Gardner, Pursuing a Right to Counsel in Civil Cases: Introduction and Overview, 40 ClEARINGHOUSE REv. 167 (2006). The American Bar Association, joined by a range of other state and local bar associations, unanimously passed a resolution in 2006 asserting a right to counsel in civil cases involving "shelter, sustenance, safety, health, and child custody." AMERICAN BAR ASSOCIATION TASK FORCE ON ACCESS TO CIVIL JUSTICE, REPORT TO THE HOUSE OF DELEGATES (2006), available at http:/www.americanbar.org/content/dam/aba/administrative/legal_aid_indigent_defendants/ls_sclai d_06A112A.authcheckdam.pdf. There is also a national organization that pursues the goal of Civil Gideon. NATIONAL COALITION FOR A CIVIL RIGHT TO COUNSEL, http://www.civilrighttocounsel.org/ (last visited Jan. 31, 2015). For a recent review and critique of Supreme Court jurisprudence in this area, see John P. Gross, The True Benefits of Counsel: Why "Do-lt-Yourself" Lawyering Does Not Protect The Rights of the Indigent, 43 N.M. L. Rev. 1 (2013). The most recent Supreme Court decision addressing (and denying) a right to counsel in civil cases is Turner $v$. Rogers. Turner v. Rogers, 131 S. Ct. 2507 (2011) (showing that the Court declined to find a right to counsel in a civil contempt hearing).

${ }^{94}$ Kevin R. Johnson, An Immigration Gideon for Lawful Permanent Residents, 122 YALE L.J. 2394 (2013); Andrew Scherer, Gideon's Shelter: The Need To Recognize a Right To Counsel for Indigent Defendants in Eviction Proceedings, 23 HARV. C.R.-C.L. L. REV. 557 (1988).

${ }^{95}$ A few states, for example, recognize right to counsel in cases involving "abuse/neglect, civil contempt, paternity, and civil commitment cases." John Pollock, It's All About Justice: Gideon and the Right to Counsel in Civil Cases, 39 A.B.A. Hum. RTS. 12 (2013). Another effort related to Civil 
even resolve issues facing indigents is debatable given the allocation of resources needed to meaningfully fulfill such a right. ${ }^{96}$

In any event, massive numbers of tenants in the United States do not have lawyers. Consider matters involving housing. In fora nationwide where landlordtenant matters are adjudicated, a tiny percentage of tenants have counsel. ${ }^{97}$ Russell Engler has gathered data on the issue. ${ }^{98}$ His results and other data from individual jurisdictions are sadly consistent. In New York City, $12 \%{ }^{99}$ of tenants are represented, while in Chicago the figure is $7.1 \% .{ }^{100}$ The Massachusetts judiciary reported that $8.3 \%$ of tenants are represented in Boston Housing Court. ${ }^{101}$

Consider also data relating to other kinds of proceedings. In foreclosure proceedings, $7.1 \%$ of New Jersey homeowners and $5 \%$ of homeowners in Philadelphia were represented. ${ }^{102}$ Only $25 \%$ of women seeking protective orders are represented. ${ }^{103} \mathrm{~A} \$ 10$ limit on attorney's fees in claims for veteran's benefits has the practical effect of forcing veterans to proceed pro se in these types of cases. ${ }^{104}$

Gideon directed at low-income litigants are arguments for the existence of socioeconomic rights, which would obligate government to provide food, education, and shelter. These rights, if recognized, might infer a private cause of action. Frank Michelmen has been a prolific and influential scholar in this area. See Frank I. Michelman, Socioeconomic Rights in Constitutional Law: Explaining America Away, 6 INT'L J. CONST. L. 663 (2008).

${ }^{96}$ Rebecca Aviel, Why Civil Gideon Won't Fix Family Law, 122 YALE L.J. 2106 (2013). Ironically some have argued that Gideon itself has failed to provide meaningful representation for criminal defendants. Donald A. Dripps, Why Gideon Failed: Politics and Feedback Loops in the Reform of Criminal Justice, 70 WASH. \& LEE L. REV. 883 (2013). See infra text accompanying notes 141-53.

${ }^{97}$ Matthew Desmond, Tipping the Scales in Housing Court, N.Y. TIMES (Nov. 29, 2012), http://www.nytimes.com/2012/11/30/opinion/tipping-the-scales-in-housing-court.html (describing that "[i]n many housing courts around the country, $90[\%]$ of landlords are represented by attorneys and $90[\%]$ of tenants are not").

${ }^{98}$ Russell Engler, Connecting Self-Representation to Civil Gideon: What Existing Data Reveal About When Counsel Is Most Needed, 37 FordhaM URB. L.J. 37, 46-51 (2010).

${ }^{99}$ Carroll Seron, et al., The Impact of Legal Counsel on Outcomes for Poor Tenants in New York City's Housing Court: Results of a Randomized Sirvey, 35 LAW \& SOC'Y REV. 419, 421 (2001).

${ }^{100}$ Anthony J. Fusco, Jr. et al., Chicago 's Eviction Court: A Tenant's Court of No Resort, 17 URB. L. ANN. 93, 114-16 (1979) (URB. L. ANN. is now known as WASH. U. J. URB. \& CONTEMP. L.).

101 BOS. BAR ASS'N ON THE CIVIL RIGHT TO COUNSEL, THE IMPORTANCE OF REPRESENTATION IN EVICTION CASES ANd HOMElessness PREVENTION: A RePORT ON THE BBA CiVIL Right to Counsel Housing Pllots 7 (2012); Russell Engler, And Justice for All-lncluding the Unrepresented Poor: Revisiting the Roles of the Judges, Mediators, and Clerks, 67 FORDHAM L. REV. 1987, 2057-63 (1999). "The assistance of counsel substantially enhances the probability of success." Id.

102 THE IMPORTANCE OF REPRESENTATION, supra note 101, at 4-5.

${ }^{103}$ Jane C. Murphy, Engaging with the State: The Growing Reliance on Lawyers and Judges to Protect Battered Women, 11 AM. U. J. GENDER SOC. POL'Y \& L. 499, 511 (2003).

${ }^{104}$ The Supreme Court upheld this limitation in Walters $v$. Nat'l Ass ' $n$ of Radiation Survivors. Walters v. Nat'l Ass'n of Radiation Survivors, 473 U.S. 305 (1985). 
As to the actual process accorded to low-income litigants who are pro se, perhaps Deborah Rhode has said it best: "civil courts take weeks to try a commercial dispute between wealthy businesses but give less than five minutes to decide the future of an abused or neglected child." 105 Baltimore's Rent Court, for example, has only one judge assigned per day, and yet that judge often has daily a docket of 1,050 cases. ${ }^{106}$ As a result, "the average case receives less than 30 seconds of judicial review." 107 The process here involves massive numbers of default judgments ${ }^{108}$ _not exactly the stuff of Civil Procedure classes.

Foreclosure cases are the same. The foreclosure crisis flooded courts with a volume of cases they were ill-equipped to handle. ${ }^{109}$ Scandals involving "robosigning," "robo-verification," and "rocket dockets" reflect the process accorded to such cases. ${ }^{110}$ Remarkably, even apart from the foreclosure crisis, many states have long employed "nonjudicial foreclosure" which dispenses with judicial involvement altogether. ${ }^{11}$ Even with judges, virtually no foreclosure cases have trials, cross-examinations, judges, and, overwhelmingly, attorneys. "Rocket

\footnotetext{
${ }^{105}$ Deborah L. Rhode, Access to Justice, 69 FORdHAM L. REV. 1785, 1793 (2001).

${ }^{106}$ A System in Collapse, 16 Abell Rep., no. 2, Mar. 2003, at 2. Remarkably, this is an administratively imposed limit, which means that without the limit the number would rise even higher.

${ }^{107}$ Id. Court's rarely recognize such realities, but a rare example otherwise is 144 Woodruff Corp. $v$. Lacrete. 144 Woodruff Corp. v. Lacrete, 585 N.Y.S.2d 956, 960 (N.Y. Civ. Ct. 1992) (New York City's Housing Court cases are "disposed of at an average rate of five to fourteen minutes per case, with many settlements in the range of five minutes or less").
}

${ }^{108}$ Barbara Bezdek, Silence in the Court: Participation and Subordination of Poor Tenants' Voices in Legal Process, 20 Hofstra L. Rev. 578-82; Williams v. Hous. Auth. of Balt. City, 760 A.2d 697, 705 n.6 (Md. 2000) (stating that "out of a total of 807,000 civil cases filed in [State] District Court . . nearly 570,000 were landlord-tenant cases, but only 21,000 of those landlord-tenant cases $(3.7 \%$ were contested") (citing Annual Report of the Maryland Judiciary 1998-99, Table DC-4.

109 The number of foreclosure cases rose from 800,000 in 2005 (no small number) to 2.9 million in 2010. Lydia R. Nussbaum, ADR's Place in Foreclosure: Remedying the Flaws of a Securitized Housing Market, 34 CARDOZO L. REV. 1889, 1905 (2013).

${ }^{110}$ See Ariana Eunjung Cha \& Brady Dennis, Amid Mountain of Paperwork, Shortcuts and Forgeries Mar Foreclosure Process, WASH. POST (Sept. 23, 2010), http://www.washingtonpost.com/wpdyn/content/article/2010/09/22/AR2010092206132.html (describing how "[t]he nation's overburdened foreclosure system is riddled with faked documents, forged signatures and lenders who take shortcuts reviewing borrower's files"); Andrea J. Boyack, Community Collateral Damage: A Question of Priorities, 43 LOY. U. CHI. L. J. 53, 135 (2011); Nabanita Pal, Facing Foreclosure Alone: The Continuing Crises in Legal Representation, BRENNAN CENTER FOR JUSTICE 1, 10 (2011), http://www.brennancenter.org/sites/default/files/legacy_facing_foreclosure_alone.pdf (describing signatures by a mortgage servicer employee who, in a deposition, "admitted to signing off on thousands of affidavits purporting that the servicer had a right to foreclose on homeowners - without ever reviewing the cases). Courts accommodate the influx of cases with "rocket dockets" which, in the spirit of robo-signing itself, fail to present even a façade of due process. Michael Corkery, $A$ Florida Court's 'Rocket Docket' Blasts through Foreclosure Cases, WALL ST. J. (Feb. 18, 2009), http://www.wsj.com/articles/SB123491755140004565.

111 Nussbaum, supra note 109, at 1894. 
dockets" would make for rather dull viewing. Ratings would no doubt suffer, although real-life consequences for litigants are anything but dull.

Debt collection cases are yet another example of a sham process. Peter Holland examined these cases in Maryland in 2014. "12 He describes a "shadow system" 113 that requires debtors to attend "resolution conferences" at which creditors are always represented and less than $2 \%$ of debtors are. ${ }^{114}$ The invariable "resolution" is that creditors obtain judgments against debtors, which, in turn, quickly trigger procedures to enforce the judgments. ${ }^{115}$ Holland found comparable results in other jurisdictions. ${ }^{116} \mathrm{He}$ also notes that the situation is hardly new: another study found similar results some forty years earlier. ${ }^{117}$

Moreover, these issues are not limited to urban centers. A similar lack of process characterizes "courts" in rural jurisdictions. Indeed, the level of process accorded in these courts, some of which are presided over by non-lawyers, are at times even more negligible and arbitrary than that accorded urban litigants. ${ }^{118}$

The minimal process low-income litigants experience is both characterized and facilitated by the lack of representation. The "adversary system" has been praised as "the greatest engine ever developed for the discovery of truth," 19 but lawyers fuel the engine. If there is only one lawyer the engine will not work. ${ }^{120}$

\footnotetext{
112 Peter A. Holland, Junk Justice: A Statistical Analysis of 4,400 Lawsuits Filed by Debt Buyers, 27 LOY. CONSUMER L. REV. 179 (2014).

113 Id. at 233.

${ }^{114} I d$, at 195 .

${ }^{115}$ It is ironic, if little-noticed, the largest category of rules of civil procedure involve enforcement of judgments. Nine rules of the Federal Rules of Civil Procedure address enforcement actions. One representative state-Maryland-has fifteen.

${ }^{116}$ Holland, supra note 112 , at 225-28.

117 Id. at 241 (citing David Caplovitz, Consumers in Trouble: A STUdy OF DebTORS in Default (1974)).

${ }^{118}$ A series in the New York Times traced the "process" accorded litigants in small town courts. William Glaberson, Broken Bench, How a Reviled Court System Has Outlasted Critics, N.Y. TIMES (Sept. 27, 2006), http://www.nytimes.com/2006/09/27/nyregion $/ 27$ courts.html?ex $=1170133200 \&$ en= $88 \mathrm{f} 3 \mathrm{fdf} 4193734 \mathrm{e} 4 \& \mathrm{ei}=5070 \&$ r $=0$ (describing how courts that "are the key institutions of justice in more than 1,000 small towns and suburbs across New York"-are mostly presided by non-lawyer amateur judges who "leav[e] a long trail of injustices and mangled rulings"); William Glaberson, Broken Bench, Small-Town Justice, With Trial and Error, N.Y. TIMES (Sept. 26, 2005), http://www.nytimes.com/2006/09/26/nyregion/26courts.html?ex $=1170133200 \&$ en $=$ acbfdac2ec7b48 $81 \&$ ei $=5070$ (describing courts presided over by non-lawyers, including judges with no college education, with most judges displaying "[a]n unfamiliarity with basic legal principles"); William Glaberson, Broken Bench, In Tiny Courts of N.Y., Abuses of Law and Power, N.Y. Times (Sept. 25, 2006) http://www.nytimes.com/2006/09/25/nyregion/25 courts.html?pagewanted=all\&_r $=0$.

119 John HEnRy Wigmore, EVIDENCE IN TRIAL at THE COMmON LAW $\$ 1367$ (James H. Chadboum ed. 1974).

${ }^{120}$ An irony is that there are numerous proclamations that pro se litigants should be accorded no additional assistance. Russel Engler has gathered substantial authority regarding this issue. Engler,
} 
As one scholar evocatively put it, the lack of representation leads to "[s]ilence in the [c]ourt." 121 Default judgments, rocket dockets, hallway settlements, resolution conferences, are not the stuff of courtroom drama and certainly not the stuff of intense strategic and skilled parrying between skilled advocates. It is not litigation as popularly understood.

Even when counsel is available, the process accorded low-income disputants offers a sober reminder of "litigation" in the real world. A rare and telling judicial narrative of litigation "process" in the context of poverty law is Williams $v$. Housing Authority of Baltimore City. ${ }^{122}$

The legal issue in Williams-what would be cited in a Civil Procedure textbook"123 - was subject matter jurisdiction. A Maryland court known as "Rent Court" was created by administrative fiat. It was, in effect, a non-statutory appendage to a court of general jurisdiction. This appendage, however, imposed a de facto jurisdictional limitation: the only cases that could be heard in "Rent Court" were landlord-tenant cases. Not coincidentally, the defendants in virtually all of these cases were low-income tenants. ${ }^{124}$

The opinion evokes, to a certain extent, real life-a rarity in judicial opinions. As described by the court, Appellant Ethel Williams lived in a public housing project "which was infested with rodents and other vermin; the bathtub leaked water, causing sinking holes in the floors and mildew and water damage in other rooms; and there was a large hole in the kitchen ceiling above the stove, from which debris fell into meals as she cooked." 125 An unoccupied building next to hers-also public housing_- "was filled with garbage and debris" which contributed to "rodent infestation in her home."126 This is not a difficult case both intuitively and as a matter of law: Ms. Williams has a right to live in an apartment that did not endanger her health. ${ }^{127}$

Here is the "process" she was accorded:

- Williams did not initially have a lawyer.

supra note 101 , at $20 \mathrm{~B} \mathrm{n.} 122$.

${ }^{121}$ See Bezdek, supra note 108 at 533.

122 See Williams v. Hous. Auth. of Balt. City, 760 A.2d 697 (Md. 2000).

${ }^{123}$ See supra text accompanying notes $66-80$ for a discussion of the norms of litigation as presented in legal education.

${ }^{124}$ Bezdek, supra note 108 , at 533.

${ }^{125}$ Williams, 760 A.2d at 698.

${ }^{126}$ Id. at $698-99$.

${ }^{127}$ One remedy at issue in Williams is through a procedure called "rent escrow," in which tenants deposit rent into a court escrow fund until repairs are made. MD. CODE ANN. REAL PROP. § 8-211 (West 2012). 
- Williams checked boxes on a form pleading to identify the relief she was seeking, which included a claim for breach of the covenant of quiet enjoyment and warranty of habitability.

- A hearing was held during which her claim for breach of the warranty of habitability was not heard because of "the lateness of the hour and a large docket."

- The next hearing was a month later before a different judge (there was a "Rent Court" judicial rotation system) during which the judge dismissed the claim because "Rent Court" had no jurisdiction to hear a claim for breach of warranty of habitability.

- The written order dismissing the claim was never found.

- Williams obtained counsel through a local non-profit organization and the attorney duly filed a notice of appeal from the dismissal.

- Williams' attorney requested a transcript of the hearing in order to prepare the appeal. No transcript was found, evidently because no recording of the hearing existed.

- The appeal of the "Rent Court" dismissal was wrongly characterized as "de novo" when it should have been an appeal on the record. This mistaken characterization was evidently made by a clerk, although who made this mistake and when it was made was never discovered.

- Neither Williams nor her attorney received a notice sent by the court of a "trial date," which should actually have been for an argument on an appeal. The problem was that the notice was sent to the attorney's address but was addressed to Williams. No one at the attorney's office knew who Williams was, and thus the notice was never delivered to either the attorney or to Williams.

- Neither the attorney nor Williams appeared at the purported "trial date" because they did not receive notice of it. Accordingly, the court dismissed the case.

- Williams' attorney made a motion for a new trial and the reinstatement of the appeal, and, even though the landlord did not respond or contest the motion, the motion was "summarily denied" by the court.

After the summary denial, Williams petitioned the Maryland Court of Appeals - Maryland's highest court - to hear the appeal. The Court of Appeals granted the request. At long last, the Court found that "Rent Court," along with 
its purported limited jurisdiction, did not exist under the law. The court remanded the case to adjudicate Williams' claim for breach of the warranty of habitability. ${ }^{128}$

The Williams case, sadly, is both typical and atypical of what indigent litigants experience. It is typical in terms of the slapdash procedure accorded Williams' claim, rife with errors, both administrative and judicial, at every turn. It is atypical, however, because Ms. Williams had advantages that few defendants in landlord-tenant cases have: 1) Williams was represented for at least part of the case; 2) Williams was persistent and, evidently, had time available to her to make numerous trips to the court; ${ }^{129} 3$ ) most significantly, the case led to a decision by the highest court in a state that not only granted Williams relief, ${ }^{130}$ but ostensibly, created law that would benefit future tenants in pursuing claims.

Despite this victory at the judicial level, it is unclear whether anything has changed. After all, Rent Court-now rightly identified as an administrative convenience and not a court of limited jurisdiction - can hear claims of breach of the warranty of habitability. Whether it will do so competently or meaningfully for the masses of tenants who appear before it is highly questionable.

\section{B. Criminal Cases}

The Constitution affords criminal defendants the right to a "speedy and public trial, by an impartial jury"; 131 the right to due process of law; ${ }^{132}$ and the right "to have the Assistance of Counsel." 133 These protections are illusory in almost all criminal cases. ${ }^{134}$

Like civil cases, the process accorded criminal defendants, given the massive numbers of cases that need to be adjudicated, are negligible. Criminal cases are

\footnotetext{
${ }^{128}$ Williams, 760 A.2d at 703-06.

${ }^{129}$ Many low-income litigants are hourly workers with unpredictable work schedules, limited child care, and no cars. For a compelling look at the challenges facing the working poor, see BARBARA EHRENREICH, NiCKEL AND DimEd: ON (NOT) GETTING BY IN AMERICA (2001).

${ }^{130}$ It is unclear how long it took for Ms. Williams to finally get relief upon remand. It does seem likely that a remand directly from the Maryland Court of Appeals would lift the case out of the run of the mill docket and minimize the possibility that the long list of clerical errors would repeat themselves. See generally Williams v. Hous. Auth. of Balt. City, 760 A.2d 697 (Md. 2000).

${ }^{131}$ U.S. CONST. amend. VI; U.S. CONST. art. III, $§ 2$.

132 U.S. CONST. amend. V; U.S. CONST. amend. XIV, $\S 1$.

${ }^{133}$ U.S. CONST. amend. VI.

134 The American Bar Association has "urged" states to remedy this problem, although the ABA-a non-governmental entity - has little influence apart from matters that directly affect the regulation of lawyers. ABA STANDING COMMITTEE ON LEGAL AID AND INDIGENT DEFENDANTS, EIGHT Guidelines of Public Defense Related to Excessive Workloads (Aug. 2009) http://www.americanbar.org/content/dam/aba/administrative/legal_aid_indigent_defendants/ls_sclai d_def_eight_guidelines_of_public_defense.authcheckdam.pdf.
} 
disposed of through plea bargains in $95 \%$ of cases. ${ }^{135}$ In reality criminal "procedure" is a pleading machine. The Supreme Court has said as much: "To a large extent ... horse trading [between prosecutor and defense counsel] determines who goes to jail and for how long. That is what plea bargaining is. It is not some adjunct to the criminal justice system; it is the criminal justice system." 36 The system would "crash" should more defendants demand a trial. ${ }^{137}$ This is even truer given that the criminal justice system operates in a world of mass incarceration. ${ }^{138}$ Dark humor has emerged to evoke the realities of criminal justice: "meet 'em, greet 'em, plead 'em," 139 or "McJustice."140

The huge caseloads of public defenders characterize and facilitate this system. Inadequate funding generates overwhelming numbers of cases that far exceed recommended case handling limits, ${ }^{141}$ with "[f]ifteen of twenty-two statewide defender systems hav[ing] attorney caseloads that exceed national standards." 142 Increasing caseloads far outstrip the minimal resources available to staff offices, and it is thus impossible for publicly funded attorneys to offer defendants more than cursory attention, if that. ${ }^{143}$ Indeed, public defenders can

\footnotetext{
${ }^{135}$ Michael M. O'Hear, Plea Bargaining and Procedural Justice, 42 GA. L. REV. 407, 409 (2008) (stating that "[p]lea bargaining now dominates the day-to-day operation of the American criminal justice system; about ninety-five percent of convictions are obtained by way of a guilty plea.").

${ }^{136}$ A consequence of a system that offers no individualized attention to criminal matters is the risk of wrongful convictions. Rodney Uphoff, Convicting the Innocent: Aberration or Systemic Problem?, 2006 WIS. L. REV. 739 (2006). Missouri v. Frye, 132 S.Ct. 1399, 1407 (2012) (quoting Robert E. Scott, Plea Bargaining as Contract, 101 YALE L. J. 1909, 1912 (1992)).
}

137 Michelle Alexander, Go to Trial: Crash the Justice System, N.Y. TIMES (Mar. 10, 2013), http://www.nytimes.com/2012/03/11/opinion/sunday/go-to-trial-crash-the-justice-system.html ("If everyone charged with crimes suddenly exercised his constitutional rights, there would not be enough judges, lawyers or prison cells to deal with the ensuing tsunami of litigation.").

${ }^{138}$ Michele Estrin Gilman, The Poverty Defense, 47 U. RICH. L. REV. 495, 497 (2013); Alexandra Natapoff, Misdemeanors, 85 S. CAL. L. REV. 1313 (2012) (referring to "the American penal behemoth").

${ }^{139}$ RHODE, supra note 92 , at 12.

${ }^{140}$ Stephen B. Bright \& Sia M. Sanneh, Fifty Years of Defiance and Resistance After Gideon v. Wainwright, 122 YALE L.J. 2150, 2167 (2013); see Megan Garvey \& Jack Leonard, Why L.A. Jail Cells Have Revolving Doors, L.A. TIMES (Dec. 26, 2006), http://articles.latimes.com/2006/dec/26/local/me-chum26 (describing "a justice system whose resources have not kept pace with demand").

141 State Public Defender Programs, 2007, supra at 12 (noting that in 2007, fifteen of nineteen state public defender offices in a study exceeded recommended limits).

142 Laurence A. Benner, Eliminating Excessive Public Defender Workloads, 26 CRIM. JUST. 24, 25 (2011).

${ }^{143}$ For example, the Office of the Public Defender in Luzerne County, Pennsylvania "mutinied" and refused to accept cases because inadequate funding resulted in overwhelming caseloads. See John Rudolf, Pennsylvania Public Defenders Rebel Against Crushing Caseloads, HUFFINGTON POST (June 6, 2012), available at www.huffingtonpost.com/2012/05/30/pennsylvania-publicdefenders_n_1556192.html. The "mutiny" ultimately led to a class action lawsuit, Flora v. Luzerne 
only typically allocate "seven minutes per case." 144 In one state over $90 \%$ of homicide cases involve no discovery. ${ }^{145}$

Another unfortunate result of inadequate funding is that private attorneys retained by states to represent indigent defendants are paid preposterously low fees. A range of jurisdictions offer hourly rates of $\$ 30$ to $\$ 50$, with maximums ranging from $\$ 1,000$ to $\$ 1,250 .{ }^{146}$ Low fees often generate low, if even that, quality representation. An oft-told story involves a criminal defense lawyer in a death penalty case who could name only one criminal law case: Miranda $v$. Arizona. ${ }^{147}$ The only other case he named was Dred Scott, which was actually a civil case. ${ }^{148}$ The absurdity of the current system is perhaps best illustrated by the developing jurisprudence on whether sleeping attorneys violate a criminal defendant's Sixth Amendment right to "effective assistance of counsel." 149

County. See Michael P. Buffer, Failed Public Defender Settlement Up for Discussion, CITIZENSVOICE.COM (Feb. 6, 2013) available at http://citizensvoice.com/news/failed-publicsettlement-up-for-discussion-1.

144 ACCESS to Justice INITIATIVE, U.S. DEP'T OF JUSTICE (2012), available at www.justice.gov/atj/accomplishments.pdf.

${ }^{145}$ Monroe H. Freedman, Lecture, An Ethical Manifesto for Public Defenders, 39 VAL. U. L. REV. 911,913 (2005). The precise figures are that there is no discovery in $92 \%$ of homicide cases and $93 \%$ of felonies other than homicide. Id.; see also GEORGE C. THOMAS IIl, THE SuPREME COURT ON TRIAL: HOW THE AMERICAN JUSTICE SYSTEM SACRIFICES INNOCENT DEFENDANTS 21 (2008) (stating that "[i]ndigent defendants are lucky to have a warm body and even a few minutes to discuss their case with that warm body").

${ }^{146}$ See LERMAN \& SCHRAG, supra note 77, at 798 (including statistics on fee limits in different jurisdictions).

147 Stephen B. Bright, Counsel for the Poor: The Death Sentence Not for the Worst Crime but for the Worst Lawyer, 103 YALE L.J. 1835, 1839 (1994).

${ }^{148}$ Id.

149 Tippins v. Walker, 77 F.3d 682, 687 (2d Cir. 1996) (applying a three step analysis regarding whether a sleeping attomey constitutes violation of criminal defendant's Sixth Amendment right to effective assistance of counsel: (1) did counsel sleep for repeated and/or prolonged lapses; (2) was counsel actually unconscious; and (3) were the defendant's interests at stake while counsel was asleep?). For other applications of this test, see Burdine v. Johnson, 66 F.Supp.2d 854, 863-66 (S.D. Tex. 1999), aff'd., Burdine v. Johnson, 262 F.3d 336 (5th Cir. 2001), cert. den. Cockrell v. Burdine, 122 S. Ct. 2347 (2002). The 9th Circuit has held that an attorney has to sleep during a "substantial portion of a trial" to constitute ineffective assistance. Javor v. United States, 724 F.2d 831, 834 (9th Cir. 1984). The 6th Circuit recently applied this rule in Muniz v. Smith, 647 F.3d 619 (6th Cir. 2011). The Muniz Court held that the defendant received effective assistance of counsel because Muniz's attorney "was asleep for an undetermined portion of a single . . cross-examination" and "not asleep for the entire cross since he objected near the end of the questioning." Muniz could thus not "establish that his trial counsel was asleep for a substantial portion of his trial." Id. at 623 . 
The inadequacy of resources accorded to representation for indigent criminal defendants, is not a new circumstance ${ }^{150}$ and continues to intensify. ${ }^{151}$ It renders the "right to assistance of counsel" famously set forth in Gideon v. Wainwright hollow at best. ${ }^{152}$ Under these circumstances, lawyers simply cannot provide competent representation in accordance with basic mandates of professional ethics. ${ }^{153}$

\section{CAN Litigation Be Properly Defined?}

If the dictionary is wrong, can it be set aright or are there at least trends that suggest a shift towards better capturing reality? Is there hope for a more nuanced understanding of what litigation really means for almost everyone who experiences it?

In attempting to answer this question, this Section is organized around the groups discussed in Section II above: ${ }^{154}$ the lay public, lawyers, and law students. The proffered answers are straightforward and necessarily speculative. The good news is that in some instances there is cause for measured optimism.

150 Philip B. Heymann \& Lance LIEBman, The Social Responsibilities of LaWyers: Case STUDIES 73 (1988) ("A case load of $30-45$ cases, and the constant, unyielding, wearying pressure of having six court appearances in four different courtrooms, all set for 9:00 am.").

${ }^{151}$ For statistics regarding current funding, see Hannah Levintoya et al., Charts: Why You're in Deep Trouble If You Can't Afford a Lawyer, MOTHER JONES (May 6, 2013, 5:00 AM), available at http://www.motherjones.com/politics/2013/05/public-defenders-gideon-supreme-court-charts.

(statistics on current funding); see also Erik Eckholm, Public Defenders, Bolstered by a Work Analysis and Rulings, Push Back Against a Tide of Cases, N.Y. Times (Feb. 18, 2014), http://www.nytimes.com/2014/02/19/us/public-defenders-tum-to-lawmakers-to-try-to-ease-

caseloads.html?_r $\Rightarrow$. There is, however, virtually no large scale study of the percentage of criminal defendants represented by public defenders or their equivalent. See also Erica J. Hashimoto, Assessing the Indigent Defense System in TOWARD A MORE PERFECT UNION: A PROGRESSIVE BLUEPRINT FOR THE SECOND TERM, AM. CONST. SOC'Y (Sept. 2013) available at http://www.acslaw.org/publications/issue-briefs/assessing-the-indigent-defense-system- 0 .

${ }^{152}$ See also Gideon v. Wainwright, 372 U.S. 335 (1963). Anthony Lewis' Gideon's Trumpet (1964), published shortly after Gideon was decided, traces the story of the case. In recent years many have noted the how the promise of Gideon remains unfulfilled. See also Heather Baxter, Gideon's Ghost: Providing the Sixth Amendment Right To Counsel in Times of Budgetary Crisis, MICH. ST. L. REV. 341 (2010). The fiftieth anniversary of Gideon in 2013 generated a spate of critiques. See Stephen V. Bright \& Sia M. Sanneh, Fifty Years of Defiance and Resistance after Gideon v. Wainwright, 122 YALE L.J. 2150, 2174 ("[M]ost state governments have treated the Supreme Court's decision in Gideon not as a bright star pointing the way to justice, but as an unfunded mandate to be resisted."); see also Dripps, supra note 96, at 900 (stating "Gideon's 'triumph' is [a] . . 'storybook'-an unrealized dream, a myth").

${ }^{153}$ Heather Baxter, Too Many Clients, Too Little Time: How States Are Forcing Public Defenders To Violate Their Ethical Obligations, 25 FED. SENT'G REP. 91 (2012).

${ }^{154}$ See supra text accompanying notes $7-85$. 


\section{A. The Public: No}

If public perceptions of "litigation" are to change, what "strikes the senses" must change. Public media thrives on the sensational and the outlandish. As to the poor, Dwight MacDonald wrote the following in 1963: "There is a monotony about the injustices suffered by the poor that perhaps accounts for the lack of interest the rest of society shows in them. Everything seems to go wrong with them. They never win. It's just boring."155

It is boring to cover or portray tens of thousands of daily evictions, or foreclosures, or plea bargains, or deportations. Hence, except for the occasional newspaper article about housing court or "McJustice" in criminal courts, ${ }^{156}$ there is no sustained attention on the true nature of "litigation." It does not "strike the senses," nor is it likely to.

\section{B. Law Students and Lawyers: Perhaps}

There is nothing to suggest that more lawyers will represent litigants embroiled in the mass of litigation. Indeed, there is some evidence to suggest that fewer lawyers will represent these litigants. ${ }^{157}$ Legal education, however, is changing and, as the precursor to practice, these changes suggest some cause for optimism. The 120 year hold of Langdellian pedagogy in law school ${ }^{158}$ seems, ever so slowly, to be losing its grip. A number of different trends reflect this change.

First, clinical education, which first rose to prominence in the early 1970 's, ${ }^{159}$ continues to grow and gain legitimacy in the academy. The call for a "clinical law school" is nothing new-it is traceable to at least $1896^{160}$ and has been repeated with regularity ever since. ${ }^{161}$ Now, however, there is greater recognition that clinical legal education is a particularly effective pedagogy for law students. ${ }^{162}$

\footnotetext{
155 Dwight MacDonald, Our Invisible Poor, THE NEW YORKER, (Jan. 19, 1963), available at http://www.newyorker.com/archive/1963/01/19/1963_01_19_082_TNY_CARDS_000075671?curre ntPage=all). The article is a review of Michael Harrington's famous book THE OTHER AMERICA: POVERTY IN THE UNITED STATES (1962).

${ }^{156}$ For some examples, see Desmond, supra note 97; Cha \& Dennis, supra note 110; Corkery, supra note 110; Benner, supra note 142; Rudolf, supra note 143.

${ }^{157}$ As noted above, lawyers are increasingly representing organizations, not individuals. See supra text accompanying note 82 .

${ }^{158}$ See supra text accompanying notes 67-71.

${ }^{159}$ DVD: An Oral History of Clinical Legal Education Part I, Seeds of Change, (Dis Makers 2006).

${ }^{160}$ Blewett Lee, Teaching Practice in Law Schools, 19 ANN. REP. A.B.A. 507 (1896).

${ }^{161}$ William V. Rowe, Legal Clinics and Better Trained Lawyers-A Necessity, 9 U. ILL. L. REV. 591, 595-96 (1917); Jerome Frank, Why Not a Clinical Lawyer-School?, 81 U. PA. L. REV. 907 (1933).

162 Clinical pedagogy has become highly sophisticated and well-developed over the years. For a collection of some of the more prominent articles, see ALEX J. HURDER ET AL., CLINICAL
} 
An added advantage is that clinical education necessarily exposes law students to poor people's courts because clinic students in law school usually learn about practice by representing indigents. ${ }^{163}$ Observing and experiencing these courts "strike the senses" and, presumably, will become an embedded memory wherever law students practice after law school. Law students become lawyers, and, having their senses struck, they will now know real litigation. ${ }^{164}$

Another trend gaining traction among states, albeit slowly, is to require candidates for a state bar to complete a defined number of pro bono hours. As of this writing, one state-New York-has implemented such a requirement, ${ }^{165}$ although three others are considering comparable proposals. ${ }^{166}$ The impetus behind the proposal was, as stated by New York's Chief Judge Jonathan Lippman, to "bridge the continuing access to justice gap ... which has resulted in thousands of litigants who cannot afford legal representation to pursue their basic rights involving housing, family, and other essential matters." 167 Pro bono in the New York proposal, however, can include working or "non-profit organizations," work "in the judiciary," or work in the government, all of which might or might not involve representing indigents. ${ }^{168}$ New York's initiative nevertheless would expose at least some lawyers to the realities of litigation. ${ }^{169}$

ANTHOLOGY: READINGS FOR LIVE-CLIENT CLINICS 59-118(1997). A journal devoted to clinical legal education-the Clinical Law Review—began publication in 1994. 1 CLINICAL L. REV. 1 (1994).

${ }^{163}$ Sarah Buhler, Painful Injustices: Encountering Social Suffering in Clinical Legal Education, 19 CLINICAL L. REV. 405 (2013). For a discussion on how the initial growth of clinical education was intertwined with providing assistance to the unrepresented, see PHILIP G. SCHRAG \& MICHAEL MELTSNER, REFLECTIONS ON CLINICAL LEGAL. EDUCATION 3010 (1998).

${ }^{164}$ A related development is the passage by the American Bar Association of a new requirement that law students take six credits of "experiential courses," which can include clinics, although they may also include other types of practice that do not involve poverty law. ABA STANDARDS \& RULES OF PROCEDURE FOR APPROVAL OF LAW SCHS., STANDARD 303 (2014-2015) available at http://www.americanbar.org/content/dam/aba/publications/misc/legal_education/Standards/2014_20 15_aba_standards_chapter3.authcheckdam.pdf.

${ }^{165}$ N.Y. COMP. CODES R. \& REGS. tit. 22, § 520.16 (2014).

${ }^{166}$ The other three states are California, Montana, and New Jersey. The American Bar Association monitors the status of these initiatives. Bar Pre-Admission Pro Bono, A.B.A., http://www.americanbar.org/groups/probono_public_service/policy/bar_pre_admission_pro_bono.ht $\mathrm{ml}$ (last visited Jan. 13, 2015). A Subcommittee of the ABA itself has studied the "pros and cons" of a pre-admission pro bono requirement. ABA Standing Committee on Pro Bono and Public Service, New York's 50-hour Preadmission Pro Bono Rule: Weighing the Potential Pros and Cons, A.B.A. (Oct. 2013) http://www.law.upenn.edu/live/files/2420-aba-white-paper-on-ny-pro-bono.

${ }^{167}$ Press Release, New York State Unified Court System (Sept. 19, 2012) (on file with author).

${ }^{168}$ Debate about what constitutes "pro bono" in rules of professional conduct often center on whether it should involve individual representation or other law reform/organizational representation.

${ }^{169}$ Not everyone supports pro bono as an effective means to provide representation to litigants or as a means to educate future lawyers. For example, some have argued that pro bono proposals "deflect public attention from . . . more productive ways of addressing" the "unmet legal needs" for legal services. Deborah L. Rhode, Cultures of Commitment: Pro Bono for Lawyers and Law Students, 67 
Third, at least one state has mandated an "access to justice" topic on the bar exam. ${ }^{170}$ The bar examination tends to strongly influence the law school curriculum, and even such coverage in a bar review course-heretofore hardly a source of information about the distortions of litigation-is all to the good.

Fourth, and most broadly, recent studies have proposed reform of law school pedagogy. ${ }^{171}$ For example, Roy Stuckey recommends that " $[1]$ aw schools should give more attention to educating students about the importance of providing access to justice and to instilling a commitment to provide access to justice in their students." 172 Other studies have offered comparable recommendations. ${ }^{173}$

None of these trends, on their own, portend a sea change in legal education. But there is some movement nevertheless, and this movement generates some cause for optimism, however modest, that the realities of litigation-and thus of law - will become part of what is purported to be legal education.

\section{CONCLUSION}

The dictionary definition of "litigate" - "a legal contest by judicial process" -is almost always wrong. ${ }^{174}$ It is not driven by law because the adjudicative system is far too overwhelmed to be governed by it. It is not a "contest" because the so-called "contest" is rigged to produce a preordained result.

Words matter, and when we say "litigation" it is not what litigation really is. To recall Dwight MacDonald, the realities of litigation might be boring. ${ }^{175} \mathrm{In}$ light of its tragic consequences, however, they are well worth knowing.

FORDHAM L. REV. 2415, 2424 (1999). The irony is that while this might be true, there is virtually no "public attention" anyway, so there is no "public attention" to deflect.

170 MASSACHUSETTS ACCESS TO JUSTICE COMMISSION, AdDITION OF "ACCESS TO JUSTICE" TOPIC TO THE MASSACHUSETTS BAR EXAMINATION (June 6, 2013) available at hitp://www.massaccessto justice.org/resources/amendment-bbe-rules-proposal.pdf. The Massachusetts Supreme Judicial Court has since unanimously adopted the proposal.

171 A seminal example is ABA, Legal EduCATION AND Professional Development-AN Educational ContinuUm, Report of the TASK FORCE ON LAW SCHOOLS AND THE PROFESSION: NARROWING THE GAP (1992) available at http:/www.americanbar.org/content/dam/aba/ publications/misc/legal_education/2013_legal_education_and_professional_development_maccrate_ report).authcheckdam.pdf. This effort is universally called the "MacCrate Report." Another prominent and more recent example is usually referred to as the Carnegie Report. WILLIAM M. SULLIVAN ET AL., Educating Lawyers: Preparation for the Profession of LaW (2007). See also Roy Stuckey ET AL., BEST PRACTICE IN LEGAL EDUCATION: A VISION AND A ROAD MAP 29 (2007). For an overview of these reports and other recent trends in legal education, see Lauren Carasik, Renaissance or Retrenchment: Legal Education at a Crossroads, 44 IND. L. REV. 735 (2011).

172 STUCKEY ET AL., supra note 171.

${ }^{173}$ See supra note 171 and accompanying text.

174 "Litigate," MERRIAM WEBSTER, http://www.merriam-webster.com/dictionary/litigate (last visited Jan. 13, 2015).

${ }^{175}$ See supra text accompanying notes 155 . 